\title{
Identity Politics behind the Recent Euro and Refugee Crises of the
}

\section{European Union}

\section{Ebru Oğurlu' 10}

\begin{abstract}
The recent crises in two flagship integration projects of the European Union (EU), i.e. the Euro and the Schengen integration, pose existential threats upon the Union. External shocks that revealed operational and institutional flaws within the EU have surfaced conflicts of preferences among the members and raised dubious questions about the future of integration. Although the causes and early stages of both crises had structural similarities, they resulted with completely different outcomes. This paper provides a liberal intergovernmental explanation for the divergent results of similar types of crises by referring to identity politics as the explanatory factor. It argues that the need for the collective identity in the Euro crisis and contradictions between European and national identities in the refugee crisis shaped the outcomes of the inter-governmental conferences and determined the future of each crisis.
\end{abstract}

\section{Keywords}

European Union, Euro crisis, Refugee crisis, Identity politics, Schengen crisis

\section{Avrupa Birliği'nin Avro ve Sığınmacı Krizlerinin Arkasındaki Kimlik Siyaseti}

Öz

Avrupa entegrasyonunun 1990'lardaki iki amiral gemisi olarak kabul edilen Avro ve Schengen bölgelerinde son zamanlarda gözlenen krizler bugün itibariyle Avrupa Birliği'nin varlığı için tehdit haline gelmiştir. Birliğin kurumsal ve operasyonel açıklarını ortaya çıkaran dış kaynaklı krizler üye ülkelerin öncelikleri ve tercihleri konusunda çatışmaları su yüzüne çıkarmış ve Birliğin geleceği ile ilgili olarak şüphelerin doğmasına neden olmuştur. Avro ve Schengen bölgelerinde yaşanan krizlerin sebepleri ve ilk evreleri yapısal benzerlik gösterse de sonuçları birbirinden tamamen farklıdır. Bu çalışma, liberal hükümetlerarasıcılık teorisi çerçevesinde, benzer nitelikteki iki krizin farklı neticelerini kimlik siyasetine atıfla tartışmakta ve Avro krizi esnasında açığa çıkan kolektif kimlik ihtiyacı ile sığınmacı krizi sürecinde su yüzüne çıkan Avrupa kimliği ve ulusal kimlikler arasındaki çatışmanın hükümetlerarası görüşmelerin sonuçlarını dolayısıyla krizlerin geleceğini şekillendirdiğini ortaya koymaktadır.

\section{Anahtar Kelimeler}

Avrupa Birliği, Avro krizi, Sığınmacı krizi, Kimlik siyaseti, Schengen krizi

1 Correspondence to: Ebru Oğurlu (Assoc. Prof.), European University of Lefke, Faculty of Economics and Administrative Sciences, Department of International Relations, Lefke, TRNC. E-mail: eogurlu@eul.edu.tr ORCID: 0000-0003-0538-5985 To cite this article: Ogurlu, E. (2019). Identity politics behind the recent Euro and refugee crises of the European Union. SIYASAL: Journal of Political Sciences, 28(2), 165-180. http://doi.org/10.26650/siyasal.2019.28.2.0059 


\section{Identity Politics behind the Recent Euro and Refugee Crises of the European Union}

Since 2005, the European Union (EU) has been going through a series of permanent crises within its various integration areas. The traditional rationale behind the EU integration lays in market integration, although the integration after the 1990s mostly focus on integration in sovereign powers of the member states, i.e. foreign and security policies, monetary and fiscal affairs, citizenship and migration among many others. This tendency has revealed the specific problem associated with the new and most controversial areas of the integration, i.e. "a strong functional demand for integration vs. tight political constraints on supply due to a high tendency for zero-sum conflict" (Genschel and Markus, 2017). Thus, the EU started to experience an existential threat.

The two recent crises of the EU, which are the Euro and the refugee crises, have exposed inability of the existing institutions and regulatory mechanisms to absorb the impacts of the externally originated shocks. It is interesting to see that both crises with similar characteristics have resulted in two different integration trajectories. While the Euro crisis has generated a higher level of integration through setting up new institutions and strengthening the existing ones, the refugee crisis has set disintegrative dynamics in relative terms by weakening collective response to the massive and unprecedented influx of refugees and migrants. Member states resisted the calls for institutional and regulatory reforms and failed to agree on substantial integration progress. This paper argues that different outcomes of the two crises in spite of their similarity in terms of causes and beginnings constitute a puzzle which needs an explanation. In this framework, this paper aims to address this puzzle with a theoretical structure by trying to explain why the Euro and refugee crises which have striking similarities have resulted in completely different outcomes in two different integration fields, i.e. more integration in the former and less integration in the latter. While doing this, it takes liberal intergovernmentalism as the point of departure to explain the integrative and disintegrative tendencies in the post-Euro and post-refugee crisis respectively.

Liberal intergovernmentalism claims that different national preferences of the member states in the two crises areas depend on the field of integration, national preferences and type of collective action which eventually shape the outcomes of the intergovernmental bargaining. (Moravcsik, 1998, p. 21). Referring to Moravcsik's arguments, it can be assumed that national preferences in the Euro crisis have led the member states consolidate their power as a political community acting on behalf of the whole EU with a European identity. However, national preferences in the refugee crisis prevented the member states from boosting integration in this field. Rather, they preferred turning to national identities as a solution mostly because of the increasing nationalist backlashes at the state level.

This paper argues that identity politics justifies the deepening of integration in the Euro crisis and weakening of integration in the refugee crisis at the EU level. Accordingly, identity politics is the key factor shaping attitudes of the member states in the Euro and the refugee crises, although the crises mobilized identities in opposite directions during the intergovernmental bargains. When the crises deteriorated, "survival of integration" has become the main concern for the member states of the EU (Genschel and Jachtenfuchs, 2017). In that sense, the Euro crisis, which represents not only an economic but also a 
political construction, re-revealed discussions about "who we are" (Börzel and Risse, 2018, p. 85), although the issue has been on the European agenda since the late 1980s and early 1990s. The feeling of being a European and desire to keep Europe as a collective identity forced the member states to be united. The failure would lead to disintegration as the costliest of all possible outcomes. Thus, by adhering to collective survival, they could sustain and even enhance integration in the Euro area which is also easily acceptable by the citizens at home. However, debates on the refugee crisis led to the discussions about "who the others are" and "who belongs to us" (Börzel and Risse, 2018, p. 85). Börzel and Risse (2018, p. 99) argue that the identitarian and cultural framework of these debates focus on the refugees and emphasise self and other as well as in-group and out-group distinction. Thus, being threatened by the influx of the "others" who do not belong to the European family, member states preferred focusing on the national survival and national identities. The member states, inevitably, had to retreat back from the integrative attempts and continue with their renationalized attitudes and policies. In this case, less integration seemed as the acceptable solution for public at home as well. This difference in the outcomes of crises, despite similar initial conditions, is the puzzle this paper tries to address.

\section{Liberal Intergovernmentalist Framework}

Liberal intergovernmentalism assumes "bounded state rationality", implying the rational response of the governments to the emerging crises" (Schimmelfenning, 2018, p. 1580). Their rational and strategic political decisions to meet the crisis-led reform calls demand "joint action or at least common approval" (Rittberger, Biermann, Guérin, Jadghuber and Weiss, 2017) by the member states which are the rational actors of the European integration. Thus, outcome of integration is attributed to national preference constellations and bargaining power among the member states" (Moravcsik, 1998, p. 18). Accordingly, as Frank Schimmelfenning argues national preferences mirror "the (predominantly economic) interests of powerful domestic groups; substantive integration agreements reflect the relative bargaining power of states in a situation of asymmetrical interdependence; and the design of international institutions set up for centralized monitoring, enforcement and adjudication reflects the need to establish credible intergovernmental commitments" (Moravcsik, 1998, p. 3; Schimmelfenning, 2018, p. 1580).

Political supply of integration is not unconditional due to the conflicting national preferences among the states which would impede agreements on common European rules and solution mechanisms. Integration proceeds only if it is functional for the joint interests which would be the outcome of the intergovernmental bargaining (Moravcsik, 1993, p. 473, 476). "The certainty of the gains and their distribution" (Kleine and Pollack, 2018, p. 1496) can easily stimulate member states to accommodate their conflicts in these power-based bargaining and agree on their functional needs to survive under high level of interdependence.

Referring to the above-mentioned arguments of intergovernmentalism, the following part evaluates the developments after the member states had to face an externally driven crisis. The unexpected external shocks inevitably imposed potential costs on member states which might propose political integration, if they suppose that the achievements of collective action would be much more than those of status quo. Therefore, as Andrew Moravcsik argues in the case of any external shock, preferences of the member states 
determine either to proceed or to inhibit integration (Moravcsik, 1998, pp. 24-27). National preferences, on the other hand, are shaped by "international interdependence as well as the position of the state" (Schimmelfennig, 2015, p. 191). Since interdependence and its gains may differ among the states and across the fields of integration, it leads to divergent preferences for integration depending on the interests of the state.

Under those circumstances, two main factors emerge to determine whether demands for integration can be met as the result of intergovernmental bargaining, i.e. asymmetric interdependence which might threaten integrative attempts depending on the type of joint action problem and power asymmetries which influence states' relative bargaining power and distribution of the benefits of integration (Rittberger et al., 2017). Since interdependence is an inevitable condition of integration, as Berthold Rittberger and others (2018) argue "if a state is exposed to the costs of international interdependence, it will prefer more policy coordination and policy integration to the status quo". On the other hand, different levels of interdependence leading to power asymmetries directly influence the relative bargaining power of the state and distribution of gains from further integration are effected indirectly. Since the level of interdependence and power asymmetries differ considerably in the Euro and refugee crisis, they produce very different integration trajectories despite their structural similarities.

In the Euro crisis, member states were jointly seeking more integration to avoid a "common bad" which is the breakdown of the Eurozone (Rittberger et al., 2017). Despite conflicting distributional preferences on the rescue between north and south, the member states could converge national preferences around the preservation of the Euro which has always been accepted as an instrument for the construction of the collective European identity within a highly integrated interdependence. Power asymmetries could only be recognized when the preferences of the surplus countries were reflected in rescue terms (Schimmelfenning, 2018, pp. 1582-1585).

In the refugee crisis, however, the member states had asymmetrical preferences due to the lack of an agreed "common bad" that needed to be jointly averted (Rittberger et al., 2017). A poorly integrated interdependence and its moderate exit costs revealed the power asymmetries among the least affected member states, such as Spain and Portugal, and the most affected member states including Greece, Italy, Germany and Hungary, by migratory pressures. The former group with a relatively more bargaining power was satisfied with the status quo and have resisted further integration steps in this field. To date, they either effectively thwarted or decided not to participate in any effort of the affected member states to introduce a burden-sharing mechanism among all (Rittberger et al., 2017). Therefore, member states could not develop a common interest in consolidating the Schengen regime. In the lack of common determination and collective measures, a massive influx of migrants and refugees forces some of the member states, especially those that are among the most affected members, to develop reactionary and discriminatory attitudes towards the non-Europeans perceived as a threat to Europeanness and European collectivity. Also, migration issue has become an identity problem for most of the member states. Overall, the initial crises that have developed around the macroeconomic and border policies of the member states have become politicized and transformed into identity politics for the EU as a whole. 


\section{Similarities of the Euro and the Refugee Crises}

Each crisis of the EU has its specificities and particularities. Although this assumption is valid for the Euro and refugee crisis of the EU, it is also possible to identify a number of common sources of both crises. According to Desmond Dinan, Neill Nugent and William Paterson the first one is the weak foundations of the Euro and Schengen systems. The rules of these policies were formulated under relatively stable conditions when the focus of the EU was on advancing integration further. Adequate attention was not given to whether those measures were sufficiently strong to cope with the challenges of more difficult time periods. Second, the member states of the EU are different from each other regarding their national priorities and preferences in the Euro and Schengen areas. Although it seems more possible to deal with those differences in stable time periods with fewer member states, it has become much more difficult to succeed this in a larger EU. Third, external factors represent another common source of the EU's crises. It was 20082009 sub-prime mortgage crisis and the ensuing recession in the USA which caused the Euro crisis due to the high level participation of several Euro members in the US financial market. Similarly the developments beyond the EU territories, including Iraq, Libya and Syria among many others, after 2010 also sparked the refugee crisis (Dinan, Nugent and Paterson, 2017, pp. 3-4).

It is also possible to identify the particularities of each crisis of the EU. As mentioned above, the deteriorating conditions in the US financial system was the most proximate cause of the Euro crisis which was later dramatized by the globally continuing financial crisis and economic recession. The structural weaknesses of the Euro system accentuated the impacts of the crisis. Despite its weak foundations, the Euro integration could progress successfully until 2000s when the regional and global economy was in reasonable buoyancy. The financial crisis of the US and its global repercussions has revealed questions about the sustainability of the Euro integration. One of the earliest results of this financial crisis was an unexpected drop in the capital transfers to the peripheral Eurozone members, i.e. Greece, Ireland, Spain and Portugal. This revealed the incautious lending of some European banks and excessive borrowing of some others leading to a balance of payments crisis as an inevitable outcome. Balance of payment crisis transformed into a public debt crisis by 2010 . The incapable institutional structure (the lack of a fiscal union or banking union) resulted in the lack of accessible solution to what was becoming a Eurozone crisis (Baldwin and Gros, 2015).

The refugee crisis, on the other hand, was triggered by various developments, such as armed conflicts and political turmoil far beyond the EU borders. The hope of thousands of people to live in, peaceful and stable countries pushed the migration flows from the Middle East and North Africa into the EU. However, the EU could not establish a fully functioning asylum system. The existing mechanisms were ineffective to cope with the vast numbers of people entering the territories of the EU. Thus, the porousness of the EU's external borders forced the member states to impose several temporary restrictions on free travel which undermined the Schengen integration.

Both the Euro and Schengen integrations had been "designed from the perspective of hoping for the best rather than anticipating the worst" (Dinan, Nugent and Paterson, 2017, p.7). However, when the worst occurred, the systems became inadequate to cope with. 
Initially, the Economic and Monetary Union (EMU) emerged from an intergovernmental compromise leading to a macro-economic integration which was initiated for liberalizing the capital markets in the EU and delegating monetary policy to an independent central bank. However, national authorities were given the power to keep fiscal policy and the surveillance of the banks under national control. As Schimmelfenning (n.d.) states "the EMU lacked functioning European mechanisms for the rescue or resolution of systematically relevant banks and for the rescue or orderly insolvency of member states in severe balance-of-payments crises". Any financing or bailout was prohibited under the EMU system. Consequently, a dynamic sovereign bank network emerged when the financial crisis damaged the Euro member states. What was worse is that although Eurozone countries had to confront with deteriorating balance-of-payment problems, they did not have any possibility either for currency devaluation or assistance from the Eurozone in the forms of bailouts or fiscal transfers (Schimmelfennig, n.d.). Thus, in the lack of sufficient policy instruments, deficit countries had to face with the risk of defaulting or abandoning the Euro.

Similar with the problems in the Euro integration, the Schengen system was also not adequately designed to cope with the large and sudden flow of refugees. The Schengen Agreement was originally signed "as a remedy for divisive centripetal forces which produce nationalist center-seeking and othering at defined borders" (Smith, 2015). It abolished border controls internally and fixed a common external border. However, the agreement left controlling external borders and managing asylum requests to the national authorities (de Angelis, 2017, p. 292). Thus, despite attempts to coordinate asylum rules throughout the Schengen area, unequal standards still exist in asylum procedures, accepting asylum seekers and granting refugee status.

The inherent challenges in the Euro and the Schengen systems forced the member states' governments to agree on common standards and rules to keep integration regimes functioning. Ironically, however, as Philipp Genschel and Markus Jachtenfuchs (2017) explain it "they were also trying to keep their sovereign state privileges, i.e. taxation and distribution in the EMU and border and migration policies in the Schengen". When the Euro and the Schengen regimes shattered governments, they initiated intergovernmental bargaining processes to discuss about distribution of the burdens of the crises and costs of the policy reforms. Due to their fiscal and economic positions, governments held conflicting views in the beginning (Schimmelfennig, 2018, pp. 182-183). The Northern coalition led by Germany had a favourable fiscal position and balance of payments and they were unwilling for any bail out programs. Rather they insisted on fiscal discipline and strict austerity measures on the states in crisis. The Southern coalition led by France, on the other hand, opposed the strict austerity measures and automatic sanctions. They demanded the mutualization of the debts and soft adjustment (Schimmelfennig, n.d.). In a similar way, conflicts in the intergovernmental bargains during the refugee crisis emerged from different impacts of migration flows on two different kinds of countries, i.e. affected states, either a first arrival state or a destination state that had to experience costly migratory burdens and non-affected states exposing to relatively moderate migratory pressure owing to their geographic locations off the main migration roads, or their location on transit ways. While the frontline and destination members, as the highly 
affected states, demanded the re-distribution of refugees throughout the EU, the nonaffected states, opposed such relocations (Rittberger et al., 2017).

Thus, intergovernmental conferences revealed the conflicting national preferences among the coalitions formed by the member states with similar structural positions. Negotiations among them resulted in divergent outcomes. The Euro crisis could trigger some degree of centralization with relatively more integrative dynamics when compared with refugee crisis which resulted in more disintegrative dynamics among the members. The following chapter discusses why and how the member states could agree on more integration in the Euro crisis and why they chose less integration in the field of refugee crisis.

\section{Varying Outcomes}

\section{Deepening Integration in the Euro crisis}

The expansion of the financial crisis to Europe raised psychological concerns about the survival of the European integration owing to the characteristics of the Euro as one of the symbols of integration. Any weakening in this field would pose a great risk for the whole integration. With this concern in their mind, the member states had to be united for the survival and defence of the Euro which also reflects a strong indication of the common European identity (Schimmelfennig, 2017, p. 293).

Being aware that Euro crisis is an undesirable consequence of a planned asymmetry between a complete economic and an incomplete political unification in Europe (Habermas, 2010), Europeans could agree on the reforms to deepen financial and fiscal integration and keep monetary integration undamaged. First, no bailout policy was left and deficit countries were provided with functional institutions and practices to keep them on track. Greece was provided with an ad-hoc emergency credit in April 2010. It was replaced with the European Financial Stability Facility in May 2010. The latter was succeeded by European Stability Mechanism (ESM) in September 2012 as a permanent intergovernmental financing institution. ESM imposed consolidation measures on indebted members in return for bonds provided by the debt-free members of the Eurozone. These formal steps were the safety valves of the insolvent countries. Moreover, the European Central Bank (ECB) acted as a lender of last resort for the deficit countries as well as the banks. Second, member states agreed on a stricter regulatory framework for Eurozone members to control national budgets and impose sanctions on those that violate the balanced budget rule. Third, a series of legislative regulations were introduced in order to reinforce fiscal regulation and supervision. Six Pack entered into force in December 2011 as "a concrete and decisive step towards ensuring fiscal discipline, helping to stabilise the EU economy and preventing a new crisis in the EU" (European Commission, 2011). Later, member states accepted Two-Pack in March 2013 "to strengthen the coordination and surveillance of budgetary discipline in order to ensure the EMU can function properly" (European Commission, 2013b). Lastly, Fiscal Compact entered into force in January 2013 "to reinforce the budget discipline of Euro area governments following the sovereign debt crisis that started in 2010" (European Commission, 2013a). Fourth, member states have also started to coordinate their banking standards and committed themselves in a Banking Union with three pillars, 
i.e. the Single Supervisory Mechanism, the Single Resolution Mechanism and the Single Resolution Fund which entered into force in November 2013, August 2014, and in January 2016 respectively. The new system would centralize banking supervision under the ECB by taking away member states' authorities for financial supervision. ${ }^{1}$ Thus, unprecedented collective financial responsibilities, reduction in autonomous state budgetary policies and centralized financial management enhanced integration in the Euro region. Based on all previous achievements, more recently, in December 2017, the European Commission set out a roadmap to deepen the EMU in 18 months. The Roadmap built on the vision set out in the Five Presidents' Report: Completing Europe's Economic and Monetary Union (European Commission, 2015b) and the Reflection Paper on the Deepening of the Economic and Monetary Union (European Commission, 2017a) introduced a number of initiatives including European Monetary Fund, incorporation of the Fiscal Compact into the EU law, new budgetary instruments among many others to enhance the unity, efficiency and democratic accountability of EMU by 2025 (European Commission, 2017b).

As the result of the collective measures mentioned above European member states could give rise "a little more Europe" (Dinan, Nugent and Paterson, 2017, p. 13) in the fiscal governance of the EU thanks to the intergovernmental bargains among themselves. Since the Euro integration has been vital for the whole Europe, none of the members would put it at risk (Beck, 2011). This statement does not necessitate ignoring the counter arguments saying that the Euro crisis has created deep cleavages which put the EU in existential crisis. ${ }^{2}$ In this respect it is worth remembering that the Euro crisis has upset the compromise between Britain and Euro members. By deepening up the alienation of the former from the European integration, the Euro crisis led directly to the Brexit. Moreover, the Euro crisis increased the policy and institutional distance between not only the Eurozone and the non-Eurozone members of the EU but also between the north of the Eurozone and its south by revealing the "divergences between the export-led growth strategies of the former based on wage restraint, productivity and competitiveness and demand-led growth strategy of the latter based on fiscal expansion and wage inflation" (Hall, 2012, pp. 358-359). Thus, it has shown the incongruence of managing a common currency through a plurality of decentralized economic policies among the Euro members.

\section{Towards Disintegration in the Refugee Crisis}

The EU has always been "under criticism for lacking coherent and effective migration and asylum policies which have long been difficult to forge because of national sovereignty concerns and sensitivities about minorities, integration and identities" (Archick, 2017). In

1 For details about the reforms on the way of further integration in the EMU, pls. see European Commission. (2012). Communication from the Commission - A Blueprint for a Deep and Genuine Economic and Monetary Union - Launching a European Debate. COM(2012) 777 final, 28 November 2012. Retrieved from https:// eur-lex.europa.eu/legal-content/EN/TXT/?qid=1541503456629\&uri=CELEX:52012DC0777; Juncker, J-C. (2015, June 12). Preparing for Next Steps on Better Economic Governance in the Euro Area - Analytical Note. Retrieved from https://ec.europa.eu/commission/sites/beta-political/files/analytical_note_en.pdf.

2 Since this article does not aim to discuss the disintegrative dynamics of the Eurozone crisis, for more details on the topic pls. see Fabbrini, S. (2016). Beyond Disintegration: Political and Institutional Prospects of the European Union. In B. Vanhercke, D. Natali and D. Bouget (Eds.), Social Policy in the European Union: State of Play 2016 (13-31). Brussels: ETUI aisbl; Hall, P. (2016). The Euro Crisis and the Future of European Integration. In D. Acemoğlu (ed.), The Search for Europe: Contrasting Approaches (46-67). Madrid: BBVA; Zielonka, J. (2014). Is the EU Doomed? Cambridge: Polity Press; Eichengreen, B. (2015). How the Euro Crisis Ends: Not with a Bang but a Whimper. Journal of Policy Modeling, 37(3), 415-422. 
the lack of centralization, it has become a national concern to face with the challenges of the mass influx of refugees. Unlike the tendencies in the Euro crisis, the member states could not agree on delegating their sovereignties to the supra-national EU institutions. Rather, they refrained from fulfilling even the requirements of the existing Schengen regime.

Of the 22 EU members that belong to the Schengen area including Germany, Belgium, Austria, France, Sweden, Norway and Denmark have placed border controls since the beginning of the refugee crisis. Some EU states have set fences in the Schengen territories, i.e. along the Austrian-Slovenian frontier (Alderman and Kanter, 2016).

Second, the EU as the collectivity could not introduce the system of joint responsibility or re-allocation which would replace or supplement the Dublin rules. ${ }^{3}$ Rather, in May 2016, the Commission proposed to preserve the Dublin system with the introduction of the "fairness mechanism" which will become operational if "a country is handling a disproportionate number of asylum applications" (European Commission, 2016).

Third, in October 2016, the Commission replaced Frontex with the European Border and Coast Guard Agency, including a Return Office to assist member states in returning illegal migrants to their home countries (European Commission, 2015d; European Commission, 2015c). This supra-national effort was, however, diluted by leaving the decision to the individual member in need of help rather than providing the Commission with the power to approve any measure (Barigazzi, 2016).

Despite the attempts of the EU and its member states to devise policies and take decisions, many more of them were laid out in May 2015 in the Commission's Road Map European Agenda on Migration (European Commission, 2015a), the efforts to centralize the EU's response to the refugee crisis failed. Member states preferred re-nationalized rather than supra-nationalized measures to deal with the migratory challenges and the Schengen regime weakened. Thus, the refugee crisis has threatened "many of the foundations and bases on which European integration has been built” (Buonanno, 2017, p. 122).

At this point the question is why the member states could be able to proceed with more integration in the Euro crisis and why they have reached only to a stalemate in the Schengen crisis. The following part is where this issue is discussed.

\section{Explaining Differences in Crisis Outcomes: Identity Politics}

The Euro crisis and the refugee crisis have been extremely politicized issues. As Genschel and Jahtenfuchs (2017) argue both crises reflect "problems associated with the EU's shift from market integration to the integration of core state powers". Monetary and fiscal policies of the members as well as their border and interior policies as the areas of sovereign state powers mostly lead to politicized integration. Moreover, since financial affairs of the Eurozone and the migration issue of the Schengen system are the areas of contestation in domestic politics, any common European policy in these fields would have direct impacts on the national politics and public at home. Thus, under the shadow of

3 The Dublin system is a cornerstone of the Common European Asylum System established in 2003. It is a regulatory framework determining the member states responsible for examination of asylum application. Accordingly, asylum applications have to be examined by the state through which the asylum seeker first entered the EU. The Dublin System is based on three legislative texts, i.e. The Dublin Convention of 15.06.1990, The regulation No. 343/2003 (Dublin II) and The regulation no. 604/2013 (Dublin III). 
domestic politics, the possible costs of integration among member states forced them to follow policies which would be easily acceptable by the public. In this framework, identity problem, the most sensitive one for the public, reinforced integration in the Euro crisis and triggered disintegration in the refugee crisis as the result of intergovernmental bargains.

Identity in general is a political issue and has impacts on each area of the European integration. The feeling of Europeanized identities deepens the solidarity, collectivity and integration. In the Euro crisis, debates about economic governance heavily involved identity issue because "there is a reciprocal relationship between money and collective identity" (Kaelberer, 2004). In this respect, as Thomas Risse (2003, p. 501) emphasises the former has always been a purposed tool for the construction of the latter. In line with this logic, the Euro is as much about collective identity pertaining to Europeanization as it is about economic and monetary issues (Risse, 2002). It is an explicit part of European polity and identity and "using the Euro makes citizens feel a bit more European than before" (Risse, 2003). Thus, referring to this role of the Euro as the most important symbolic reminder of a common European identity, the Eurozone and its protection is supposed to represent the nucleus of the European integration at the same time. As it is exemplified by Schimmelfenning (2015, p. 182), since the political and social identity of the EU has been under threat during the Euro crisis, the leading political actors in various member states including Germany, France and Italy declared "their will to do everything ... to defend, to preserve and consolidate the Eurozone".

From the beginning of the crisis, governments could unify around the survival and defence of Euro, despite the fact that they strongly disagreed on the ways of the achievement of this goal. ${ }^{4}$ The evaluation of decisions and policies of Germany and France as the two leading members of the Euro area, as discussed following, would reflect the common tendencies among all EU members. In the initial stages of the crisis, Germany was determined to act decisively if the future of the euro is under risk. In this respect, German Chancellor Angela Merkel defended the rescue of Greece. Despite an unfavourable domestic climate, German Parliament approved the Greek bailout plan in May 2010. As Edward Cody (2010) noted "Merkel argued that Germany must participate in the $\$ 141$ billion rescue fund to preserve the stability of the Euro and the financial health of the 27-nation European Union". Thus she proved the commitment of Germany to defend the safety of the Euro and the entire Euro area. Two years later, in a speech before the European Parliament she reiterated her arguments about the importance of the Euro and said that "... our single currency is so much more than just a currency. It is the symbol for the peaceful and democratic unification of Europe we have achieved. It is the symbol for a Europe of peace, prosperity and progress" (Merkel, 2012). More recently, as Paul Carrel and Andreas Rinke (2018) wrote "Merkel urges for a spirit of compromise on reforming the Euro zone". Similarly, former French President Nicolas Sarkozy declared "if we created the Euro, we cannot let a country fall that is in the Eurozone" (Balmer, 2010) and expressed French determination to support both Greece and the Euro. Supporting his ideas then French Budget Minister François Baroin told that "there is no doubt over the determination of the Eurozone ... and therefore the stability of our currency" (France 24, 2010).

4 For the national differences about the means of preserving the Euro, pls. see Schild, J. (2013). Leadership in Hard Times - Germany, France, and the Management of the Eurozone Crisis. German Politics and Society, $106(1), 24-47$. 
Since the emergence of the crisis, not only the individual members but also the EU as a collectivity has always affirmed their commitment "to the Euro and to do whatever is needed to ensure the financial stability of the Euro area as a whole and its Member States" (Council of the European Union, 2011). They have kept their positions in the later stages of the crisis while agreeing on the common measures to defend and consolidate Euro as mentioned in the previous parts. Citizens of the Eurozone members have also tended to proceed with the integration. According to the results of the last Eurobarometer on the Euro Area released in October 2017, "two-thirds of respondents (64\%) think that having the Euro is a good thing for their country and a quarter (25\%) think that it is a bad thing" (European Commission, 2017c). Comparing with the results of 2016, this shows a remarkable rise in the number of citizens thinking that having Euro is good thing for their countries.

Overall, as it is also argued by Tanja A. Börzel and Thomas Risse (2018, pp. 9798), beyond its economic achievements, the political and sociological implications and reflections of the Euro, as the common collective fate, have convinced the member states to keep Eurozone integration intact. The progress in the Eurozone integration was used as a tool to strengthen the feelings of the collective identity.

In a similar way, identity politics dominated debates during the refugee crisis, albeit in an opposite direction. As Natalie Nougayrède shows migration issue has divided the Europeans into two camps: "liberal internationalists attached to fundamental asylum principles or to the dream of a borderless world and xenophobic fence-builders who see migration as a modern version of barbaric invasion threatening culture and civilization" (Natalie Nougayrède, 2016). This division, however, hindered a more pragmatic humanitarian reaction to the crisis. An examination of a few member states in terms of their initial reactions to refugee crisis and their treatment of the refugees would be helpful to see the unbridgeable gap among all members. When the crisis erupted, Germany was at the forefront of the reception of huge numbers of migrants and refugees coming to the EU generally and to the country specifically. First, it proposed a pan-European solution for fairer allocation of asylum seekers. In Fall 2015, as a reaction to the inhuman practices of the Hungarian government to the refugees, Germany decided to take in refugees stranded in Hungary. Thus, the number of people coming to Germany increased substantially (Engler, 2016; Akrap, 2015). In a similar way, former Italian Prime Minister Matteo Renzi constantly called for European solidarity to cope with the challenges of inflows. He threatened the EU with "issuing migrants with temporary visas allowing them to travel elsewhere in Europe" (Traynor, 2015a; France-Peresse, 2015) in the lack of any deal for burden sharing among all members of the EU.

Unlike Germany and Italy, France has always been reluctant to open its doors to migrants and refugees. It preferred holding centres or detention camps in neighbouring countries under the EU control or inside the EU if necessary (though preferably not on their soil) and sanctions against member states that fail to take their burden. When the crisis deteriorated in Fall 2015, Sarkozy called for "the suspension of the Schengen accord that lets people travel without passport checks between 26 European countries, saying that the continent's migration crisis had made it unworkable" (Brian, 2015). The former Dutch Prime Minister Mark Rutte supported Sarkozy and said that "No one 
wants to kill Schengen, but if it is only a fair-weather system then it cannot survive" (Chrisafis, Elliott and Treanor, 2016). Similar to French and Dutch perceptions, Hungary adopted a much severer anti-refugee policy. Hungary was one of the directly exposed member states to refugee crisis due to its closeness to the Western Balkans and reacted very harshly to the inflow of increasing numbers of migrants and refugees to the country. Hungary's nationalist prime minister Viktor Orbán said that "Everything which is now taking place before our eyes threatens to have explosive consequences for the whole of Europe" (Traynor, 2015b). As Jake Flanagin (2015) reports "he further objected to plans put forth by the governments of Germany, France, and Italy to redesign Europe's asylum procedures, and require member states to accept refugee quotas based on national wealth and the capabilities of respective social welfare systems". Based on this strategy, Hungary first introduced internal border control due to a large influx of migrants on its land border with Slovenia. Then, it unilaterally built a fence on its border with Serbia and later on with Croatia to reduce the inflow of migrants into and throughout the country.

The above-mentioned statements prove the divergences among the positions of the member states. Even today there seems no prospect for the possibility of a common European response to the refugee crisis. One of the recent EU summits in June 2018 revealed the lack of a common migrant and asylum policy and the split among the leaders of the EU over the ongoing crisis (BBC News, 2018a). What is worse is that perceptions of migrants as threats triggered identity politics in Europe and symbolized the return to instinctive national sentiments (Postelnicescu, 2016, p. 204). Insiders versus outsiders narrative of the refugee crisis only amplified exclusive nationalism and forced governments to re-treat into unilateral policies at the expense of the collective solutions (Hooghe, Laffan and Marks, 2018, p. 4). After a huge refugee inflow into the borders of the EU, the member states appealed to national identities, national values, national interests and national borders (Postelnicescu, 2016, p. 205). With their exclusionary vision, most of the member states mobilized their nationalist feelings and identities and put severe restrictions on collective and coordinated European response to refugee flows.

Today, the real crisis of the EU is the racist and nationalist backlash throughout the continent (Fotiadis, 2016). The recent election results in most of the EU member states prove that nationalist and far-right parties with their anti-immigration and Eurosceptic agenda have made significant electoral gains. In Germany, Alternative for Germany (AfD) as a far-right party gained seats in the Federal Parliament for the first time in 2017. In the same year, another right-wing populist party in Austria, the Freedom Party, became a partner in the coalition government. In April 2018, Orbán who presents himself as the defender of Hungary and Europe against the Muslim migrants gained a decisive victory in the elections which was dominated by immigration. In Italy, the populist and Eurosceptic Five Star Movement and right-wing League formed a coalition government in June 2018. In Sweden, right-wing populist and nationalist Sweden Democrats could make remarkable gains in September 2018 general elections (BBC News, 2018b). These results prove that the recent refugee crisis has awakened "nationalistic populism in Europe with a disintegrative impact on the Union” (Dağ1, 2018, p. 12).

Mobilization of nationalism and national identities, however, symbolizes "decades of unresolved issues related to the development of a supra-national European identity 
and the role of state and national borders that stubbornly remain in conflict with the idea of Europe as an identity space" (Smith, 2015). The refugee crisis reveals different degrees of national belonging to the European project and idea (Postelnicescu, 2016, p. 207). Thus, the type of the collective action problem obstructed any solution through intergovernmental bargaining mostly because of the sensitivity of the issue for national survival. Since the members could not find a common denominator in those conferences, they could not upgrade the common European interest in the refugee crisis. Rather, as several studies show it attachment to the nation and national identity has become a strong indication of negative attributes towards European integration (Hobolt and Wratil, 2015, p. 240; Hooghe and Marks, 2004, pp. 415-420). Consequently, more states have opted to postpone their participation in the Schengen regime suggesting that "future common migration or refugee policies may continue to be driven by the consistent xenophobia and fear-mongering over the other" (Smith, 2015) with the eventual result of much weaker integration in this area.

\section{Conclusion}

The Euro and the refugee crises originated from exogenous shocks. Both of them turned into integration crises due to the internal shortcomings of the integration regimes. However, they resulted in two different outcomes, eventually. This paper tried to show how identity politics have inclined the member states to pursue more integration in the Euro crisis while the same concern has divided them deeply and threatened membership solidarity in refugee crisis.

In this framework, the paper agrees with the existing literature arguing that interdependence is central condition of integration and demand for interdependence varies across issues and states. So, level of interdependence among the member states in the Euro and Schengen integrations and member states' preferences in these areas justify divergent outcomes in the Euro and the refugee crises. In both of the externally driven crises, the main objective for the member states was to preserve the already achieved benefits of the integration in the Eurozone and the Schengen systems. Therefore, in the highly integrated and interdependent Euro area, political cost of the common bad in the Euro crisis (the breakdown of the Eurozone) forced the member states through further integrative measures. The lack of such a common bad in the poorly integrated and interdependent Schengen area led to the collapse of existing achievements. The member states tended into the disintegrative measures with the same concern in their minds which is to minimize the political costs of refugee crisis as far as possible.

As a contribution to the existing literature, this paper argues that the pillars of liberal intergovernmentalism, i.e. divergent national interests, intergovernmental bargaining, and level of interdependence offer a reasonable explanation in justifying variations of outcomes in the crises. Accordingly, highly politicized intergovernmental conferences led to the emergence of two different groups of the members in the Euro and the refugee crises, i.e. creditors vs. debtors in the former and affected states vs. non-affected states in the latter. The divisions between two groups and their bargains shaped the results of the conferences by mobilizing identities in different ways and led to variations in the outcomes. Politicization of intergovernmental conferences during the Euro crisis raised 
questions about Europeanness and solidarity among the Europeans. The members agreed that solidarity would be the only way for eliminating the negative externalities of the Euro crisis. They also realized that solidarity could only be achieved by reinforcing Europeanness and European collective identity. Thus keeping Euro and monetary unification intact has become a central tool for the viability and credibility of the EU as a political community. Highly politicized intergovernmental conferences during the refugee crisis raised the issue of "us vs. them" or "ingroup and outgroup" division and prevented the collective action due to the priority of national identities over the European ones. In the areas that are perceived as threat to national sovereignty or national identity, member states easily left the already achieved integrative attempts and turned to their national settings. Thus, characteristics of the field of integration and type of collective action as well as its impact on the member states justify divergent outcomes of the intergovernmental bargaining in the Euro crisis and the refugee crisis.

Grant Support: The author received no financial support for this work.

\section{References}

Akrap, D. (2015, September 6). Germany's Response to the Refugee Crisis is Admirable. But I Fear it cannot Last. The Guardian. Retrieved from https:/www.theguardian.com/commentisfree/2015/sep/06/germanyrefugee-crisis-syrian.

Alderman, L. and Kanter, J. (2016, March 1). Europe's Border Checks Become Economic Choke Points. The New York Times. Retrieved from https://www.nytimes.com/2016/03/02/business/international/europes-newborder-controls-exact-a-cost.html.

Archick, K. (2017, February 27). The European Union: Current Challenges and Future Prospects. (Congressional Research Service, 7-5700). Retrieved from https://fas.org/sgp/crs/row/R44249.pdf.

Baldwin, R. and Gros, D. (2015, November 27). What Caused the Eurozone Crisis? (CEPS Commentary). Retrieved from https://www.ceps.eu/publications/what-caused-eurozone-crisis.

Balmer, C. (2018, November 1).If Greece falls, Euro is Pointless: Sarkozy. Reuters World News. Retrieved from https://www.reuters.com/article/us-greece-france-sarkozy/if-greece-falls-euro-is-pointless-sarkozyidUSTRE6250YC20100306.

Barigazzi, J. (2016, April 21). Interior Ministers Sign off on EU Coast Guard. Politico. Retrieved from https://www.politico.eu/article/interior-ministers-sign-off-on-eu-coast-guard-december-mediterranean-sea/.

BBC News. (2018a, June 29). Migrant Crisis: EU Leaders Split Over New Migrant Deal. Retrieved from https://www.bbc.com/news/world-europe-44660806.

BBC News. (2018b, September 10). Europe and Nationalism: A Country-by-Country Guide. Retrieved from https://www.bbc.com/news/world-europe-36130006.

Beck, U. (2011, September 29). Cooperate or Bust - The Existential Crisis of the European Union. Eurozine. Retrieved from https://www.eurozine.com/cooperate-or-bust/.

Börzel, T. A. and Risse, T. (2018). From the Euro to the Schengen crises: European integration theories, politicization, and identity politics. Journal of European Public Policy, 25(1), 83-108.

Brian, L. (2015, September 10). France's Sarkozy says Borderers Europe Untenable in Migrant Crisis. Reuters World News. Retrieved from https:/www.reuters.com/article/us-europe-migrants-sarkozyidUSKCN0RA1LI20150910.

Buonanno, L. (2017). The European Migration Crisis. In D. Dinan, N. Nugent and W. E. Paterson (Eds.), The European Union in Crisis (pp. 100-130). London: Palgrave.

Carrel, P. and Rinke, A. (2018, April 19). Merkel urges compromise, Macron wants solidarity on euro zone reforms. Reuters World News, Retrieved from https://www.reuters.com/article/us-germany-france/merkelurges-compromise-macron-wants-solidarity-on-euro-zone-reforms-idUSKBN1HP391.

Chrisafis, A., Elliott, L. and Treanor, J. (2016, January 22). French PM Manuel Valls says Refugee Crisis is Destabilising Europe. The Guardian. Retrieved from https://www.theguardian.com/world/2016/jan/22/ french-pm-manuel-valls-says-refugee-crisis-is-destabilising-europe.

Cody, E. (2010, May 7). Greek bailout plan approved by German Parliament. Washington Post. Retrieved from November 01, 2018. http://www.washingtonpost.com/wp-dyn/content/article/2010/05/07/ AR2010050701987.html?noredirect $=$ on

Council of the European Union. (2011, July 21). Statement by the Heads of State or Government of the Euro Area and EU Institutions. Retrieved from https://www.consilium.europa.eu/media/21426/20110721statement-by-the-heads-of-state-or-government-of-the-euro-area-and-eu-institutions-en.pdf. 
Dağı, D. (2018). EU's Refugee crisis: From supra-nationalism to nationalism? Journal of Liberty and International Affairs, 3(3), 9-19.

de Angelis, G. (2017). Political legitimacy and the European crisis: Analysis of a faltering project. European Politics and Society, 18(3), 291-300.

Dinan, D. Nugent, N. and Paterson, E. W. (2017). A Multi-dimensional Crisis. In D. Dinan, N. Nugent and W. E. Paterson (Eds.), The European Union in Crisis (pp. 1-15). London: Palgrave.

Eichengreen, B. (2015). How the Euro crisis ends: Not with a Bang but a Whimper. Journal of Policy Modeling, $37(3), 415-422$.

Engler, M. (2016, May 11). Germany in the Refugee Crisis - Background, Reactions and Challenges. Vocal Europe. Retrieved from https://www.vocaleurope.eu/germany-in-the-refugee-crisis-background-reactionsand-challenges.

European Commission. (2011). EU Economic Governance 'Six-Pack'Enters into Force. 12 December 2011. Retrieved from http://europa.eu/rapid/press-release_MEMO-11-898_en.htm.

EuropeanCommission.(2012).Communicationfromthe Commission-ABlueprintforaDeepandGenuineEconomic and Monetary Union - Launching a European Debate. COM (2012) 777 final, 28 November 2012. Retrieved from https://eur-lex.europa.eu/legal-content/EN/TXT/?qid=1541503456629\&uri=CELEX:52012DC0777.

European Commission. (2013a). The Fiscal Compact - Taking Stock. January 2013. Retrieved from https://eurlex.europa.eu/legal-content/EN/ALL/?uri=URISERV\%3A1403_3.

European Commission. (2013b). 'Two-Pack' Completes Budgetary Surveillance Cycle for Euro Area and Further Improves Economic Governance. 12 March 2013. Retrieved from http://europa.eu/rapid/pressrelease_MEMO-13-196_en.htm.

European Commission. (2015a). Communication from the Commission to the European Parliament, Communication from the Commission to the European Parliament, the Council, the European Economic and Social Committee and the Committee of the Regions: A European Agenda on Migration. COM(2015) 240 final, 13 May 2015. Retrieved from https://ec.europa.eu/home-affairs/what-we-do/policies/europeanagenda-migration_en.

European Commission. (2015b). The Five Presidents' Report: Completing Europe's Economic and Monetary Union. 22 June 2015. Retrieved from https://ec.europa.eu/commission/publications/five-presidents-reportcompleting-europes-economic-and-monetary-union_en.

European Commission. (2015c). Managing the Refugee Crisis: State of Play of the Implementation of the Priority Actions under the European Agenda on Migration. COM (2015) 510 final, 14 October 2015. Retrieved from https://ec.europa.eu/home-affairs/what-we-do/policies/european-agenda-migration/ proposal-implementation-package_en.

European Commission. (2015d). Proposal for a Regulation of the European Parliament and of the Council on the European Border and Coast Guard and Repealing Regulation (EC) No 2007/2004, Regulation (EC) No 863/2007 and Council Decision 2005/267/EC. COM (2015) 671 final, 15 December 2015. Retrieved from https://eur-lex.europa.eu/legal-content/EN/TXT/?uri=celex\%3A52015PC0671.

European Commission. (2016). Towards a Sustainable and Fair Common European Asylum System. [Press release]. 4 May 2016. Retrieved from http://europa.eu/rapid/press-release_IP-16-1620_en.htm.

European Commission. (2017a). Reflection Paper on the Deepening of the Economic and Monetary Union, COM (2017) 291, 31 May 2017. Retrieved from https:/ec.europa.eu/commission/publications/reflectionpaper-deepening-economic-and-monetary-union_en.

European Commission. (2017b). A Roadmap for Deepening Europe's Economic and Monetary Union. 6 December 2017. Retrieved from http://europa.eu/rapid/press-release_IP-17-5005 en.htm.

European Commission (2017c). Flash Eurobarometer 458 - The Euro Area. Décember 2017. Retrieved from http:/ec.europa.eu/commfrontoffice/publicopinion/index.cfm/Survey/getSurveyDetail/instruments/ FLASH/surveyKy/2158.

Fabbrini, S. (2016). Beyond Disintegration: Political and Institutional Prospects of the European Union. In B. Vanhercke, D. Natali and D. Bouget (Eds.), Social Policy in the European Union: State of Play 2016 (1331). Brussels: ETUI aisbl.

France 24. (2010, April 29). France is 'Fully Determined' to Help Greece. Retrieved from https://www.france24. com/en/20100429-france-fully-determined-help-greece-imf-eu--france-francois- baroin.

Fotiadis, A. (2016, February 25). This Racist Backlash against Refugees is the Real Crisis in Europe. The Guardian. Retrieved from https://www.theguardian.com/commentisfree/2016/feb/25/racist-backlashagainst-refugees-greece-real-crisis-europe.

France-Peresse, A. (2015, June 15). We Will Hurt EU if Migrant Crisis is not Fixed, says Italian PM Matteo Renzi. The Guardian. Retrieved from https://www.theguardian.com/world/2015/jun/15/we-will-hurt-eu-ifmigrant-crisis-is-not-fixed-says-italian-pm-matteo-renzi.

Genschel, P. and Jachtenfuchs, M. (2017). From Market Integration to Core State Powers: The Eurozone Crisis, The Refugee Crisis and Integration Theory. (EUI RSCAS Working Papers 26). Retrieved from http:// cadmus.eui.eu/handle/1814/46424.

Habermas, J. (2010, June 9). Germany and the Euro-Crisis. The Nation. Retrieved from https://www.thenation. com/article/germany-and-euro-crisis. 
Hall, P. (2012). The Economics and Politics of the Euro Crisis. German Politics, 21(4), 355-71.

Hall, P. (2016). The Euro Crisis and the Future of European Integration. In D. Acemoğlu (ed.), The Search for Europe: Contrasting Approaches (46-67). Madrid: BBVA.

Hobolt, S. B. and Wratil, C. (2015). Public Opinion and the Crisis: The Dynamics of Support for the Euro. Journal of European Public Policy, 22(2), 238-256.

Hooghe, L. and Marks, G. (2004). Does Identity or Economic Rationality Drive Public Opinion on European Integration? Political Science \& Politics, 37(3), 415-20.

Hooghe, L., Laffan, B. and Marks, G. (2018). Introduction to theory meets crisis collection. Journal of European Public Policy, 25(1), 1-6.

Jake, F. (2015, September 3). Hungary's Leader is Determined to keep Europe for Europeans, Even as Refugees Die. Quartz. Retrieved from https://qz.com/494836/hungarys-leader-is-determined-to-keep-europe-foreuropeans-even-as-refugees-die/.

Juncker, J.-C. (2015, June 12). Preparing for Next Steps on Better Economic Governance in the Euro Area-Analytical Note. Retrieved from https://ec.europa.eu/commission/sites/beta-political/files/analytical_note_en.pdf.

Kaelberer, M. (2004). The Euro and European identity: Symbols, power and the politics of European Monetary Union. Review of International Studies, 30(2), 161-178.

Kleine, M. and Pollack, M. (2018). Liberal intergovernmentalism and its critics. Journal of Common Market Studies, 56(7), 1493-1509.

Merkel, A. (2012, November 7). Speech by Federal Chancellor Angela Merkel in the European Parliament in Brussels. Speech, Brussels. Retrieved from https://archiv.bundesregierung.de/archiv-en/hidden-hiernur-knoten-verlinken-die-auch-publiziert-sind-fuer-preview-elemente-test-etc-nur-preview-hiddennode-verwenden/homepage/speech-by-federal-chancellor-angela-merkel-in-the-european-parliament-inbrussels-606998

Moravcsik, A. (1993). Preferences and power in the European community - A liberal intergovernmentalist approach. Journal of Common Market Studies 31(4), 473-524.

Moravcsik, A. (1998). The Choice for Europe - Social Purpose and State Power from Messina to Maastricht. New York: Cornell University Press.

Nougayrède, N. (2016, October 31). Refugees aren't the Problem. Europe's Identity Crisis is. The Guardian. Retrieved from https:/www.theguardian.com/commentisfree/2016/oct/31/refugees-problem-europeidentity-crisis-migration.

Postelnicescu, C. (2016). "Europe's New Identity: The Refugee Crisis and the Rise of Nationalism. Europe's Journal of Psychology, 12(2), 203-209.

Risse, T. (2002, December 6-8). The Euro and Identity Politics in Europe. Paper presented at the Year of the Euro Conference, University of Notre Dame. Retrieved from http://userpage.fu-berlin.de/ atasp/ texte/021202_risse_euroidentity.pdf.

Risse, T. (2003). The Euro between National and European identity. Journal of European Public Policy, 10(3), 487-505.

Rittberger, B., Biermann, F., Guérin, N., Jagdhuber, S. and Weiss, M. (2017, May 4-6). Explaining Uneven EU Integration Trajectories: A Comparison of the Euro Crisis and the Refugee Crisis. Paper presented at $15^{\text {th }}$ Biannual European Union Studies Association (EUSA) Conference, Miami. Retrieved from https:// eustudies.org/conference/papers/download/267.

Schild, J. (2013). Leadership in hard times - Germany, France, and the management of the Eurozone crisis. German Politics and Society, 106(1), 24-47.

Schimmelfennig, F. (2015). Liberal intergovernmentalism and the Euro Area Crisis. Journal of European Public Policy, 22(2), 177-95.

Schimmelfennig, F. (2017). Theorising Crisis in European Integration. In D. Dinan, N. Nugent and W. E. Paterson (Eds.), The European Union in Crisis (pp. 316-335). London: Palgrave.

Schimmelfenning, F. (2018). Liberal intergovernmentalism and the crises of the European Union. Journal of Common Market Studies, 56(7), 1578-1594.

Schimmelfennig, F. (n.d.). European Integration (Theory) in Times of Crisis - A comparison of the Euro and Schengen crises. Retrieved from https:/www.eui.eu/Documents/RSCAS/JMF-25-Presentation/ Schimmelfennig-European-Integration-in-Crisis-RSC.pdf.

Sides, J. and Citrin, J. (2007). European opinion about immigration: The role of identities, interests and information. British Journal of Political Science, 37(3), 477-504.

Smith, D. (2015, September 17). The Lives of Others: Refugees, Crisis, and National Identity in Europe's Borderlands. Borderlands History. Retrieved from https://borderlandshistory.org/2015/09/17/thelives-of-others-refugees-crisis-and-national-identity-in-europes-borderlands/.

Traynor, I. (2015a, June 16). Italy threatens to give Schengen Visas to Migrants as EU Ministers Meet. The Guardian. Retrieved from https:/www.theguardian.com/world/2015/jun/15/italy-threatens-to-giveschengen-visas-to-migrants-as-eu-dispute-deepens.

Traynor, I. (2015b, September 3). Migration Crisis: Hungary PM says Europe in Grip of Madness. The Guardian. Retrieved from https://www.theguardian.com/world/2015/sep/03/migration-crisis-hungary-pmvictor-orban-europe-response-madness.

Zielonka, J. (2014). Is the EU Doomed? Cambridge: Polity Press. 